\title{
The Effect of Physical Fitness on Body Fat
}

\author{
Asep Prabowo*, Resty Gustiawati, Dian Pujianto, Eka Purnama Indah, Palmizal Abu Hanifah, \\ Sahabuddin
}

Physical Education and Sports, Graduate School of Universitas Negeri Jakarta, Indonesia

Received January 29, 2021; Revised March 25, 2021; Accepted April 15, 2021

\section{Cite This Paper in the following Citation Styles}

(a): [1] Asep Prabowo, Sofyan Hanif, James Tangkudung , "The Effect of Physical Fitness on Body Fat," International Journal of Human Movement and Sports Sciences, Vol. 9, No. 4, pp. 615 - 621, 2021. DOI: 10.13189/saj.2021.090402.

(b): Asep Prabowo, Sofyan Hanif, James Tangkudung (2021). The Effect of Physical Fitness on Body Fat. International Journal of Human Movement and Sports Sciences, 9(4), 615 - 621. DOI: 10.13189/saj.2021.090402.

Copyright@2021 by authors, all rights reserved. Authors agree that this article remains permanently open access under the terms of the Creative Commons Attribution License 4.0 International License

\begin{abstract}
This study aimed to determine the effects of physical fitness on body fat. Research methods: The researcher implemented causal studies and path analysis testing Causal studies, aiming to determine whether the independent variable or dependent variable affected the outcome. In causal studies, the cause is considered as the independent variable, while the effect is the dependent variable. 14 respondents were selected by purposive sampling. Harvard step test was used in order to measure the physical fitness, and Bioelectrical Impedance Analysis (BIA) was used in order to measure the body fat. The findings of this study are the path coefficient value of the physical fitness on body fat is -0.212 , while the value of $\mathrm{t}$-count is -2.468 . Therefore, the value of $\mathrm{t}$-count is smaller than t-table, while the degree of freedom $=9$ and $\alpha=0.05$, such as -2.26 , and the probability value of Sig. $(0.036)<$ significant level (0.05). In other words, physical fitness significantly has direct negative effect on body fat. In conclusion, physical fitness has a significant and direct negative effect on body fat. Even when the athlete's physical fitness is better, it does not guarantee his body fat is also good.
\end{abstract}

\section{Keywords Physical Fitness, Body Fat}

\section{Introduction}

Why athletes should consult with a sports nutritionist? The nutritionists reveal that the athletes come to have a consultation about how to lose weight, especially in losing body fat. Their low body weight is useful in restricting the energy while doing several activities, increasing the body temperature, and supporting the mobility in order to prevent any injuries due to limited space (Lanham-New, Macdonald., \& Roche, 2016)

Mostly, obesity is caused by a nutrient excess. In addition, obesity, especially abdominal obesity has built up to the extent which is likely to have a negative impact on health, such as cardiovascular and cancer. Regarding the psychological aspects of obesity, obesity can increase the risk of depression, bipolar, panicity, anxiety, and other negative impacts on humans' health; it can increase the risk of mortality, disability, and low quality of life.

The obesity or excess body fat phenomenon needs appropriate solutions such as implementing several techniques that can produce the best result, in order to achieve a healthy lifestyle.

According to Syakhustiani (2014), exercise is one of the factors that influence someone's physical fitness. By conducting regular exercise, it can strengthen cardiovascular and reduce the body fat, or in other words, the whole organs can be adapted to the exercise loads.

Sharkey (2012) stated "What are the criteria of an ideal weight?" First, we have to reduce the body fat to the minimum amount: the minimum amount of body fat with good health and good nutrition can be around $5 \%$ for youth and $11 \%$ for young women. Wrestlers mostly have $5 \%$ body fat, and female runners have $7 \%$ body fat (while the male runners can have $5 \%$ body fat). However, it is not suggested that all males and females should reach those body fat percentages, while the coach only suggests that the body fat percentage should be as low as possible, depend on someone's health and capability.” 
According to the scholars, many people might have good tastes and can eat anything and anytime, but when they have normal digestive organs, they will eat sufficiently and prevent an obesity. Obesity is generally caused by eating too much and the excess of calories from any food sources.

Body fat can be found in human body. Conseptually, body fat is the amount of fat which represents the proportion of human's body weight, and it might have certain conditions, such as high blood pressure, heart diseases, diabetes, and cancer.

According to Lanham-New et al., (2016), "Obesity is defined as the excessive amount of body fat. The sufferer will have different body size, different body fat, and it cannot be identified by measuring the amount of absolute fat. For example, the first person has $20 \mathrm{~kg}$ body fat and $60 \mathrm{~kg}$ body weight resulted 33\% body fat percentage, as follows:

$$
20 / 60 \times 100=33 \%
$$

Meanwhile, the second person who has $24 \mathrm{~kg}$ body fat and $80 \mathrm{~kg}$ body weight resulted 30\% body fat percentage, as follows:

$$
24 / 80 \times 100=30 \% .
$$

It can be seen that the first person has lower body mass, but his body fat percentage is higher than the second person. The category of body fat is as follows:

Table 1. ACSM recommended levels of percent body fat

\begin{tabular}{|c|c|c|c|c|c|c|}
\hline \multirow{2}{*}{ Gender } & \multicolumn{5}{|c|}{ Age (Year) } \\
\cline { 2 - 7 } & Essential & Minimal & Athletic & $\leq 34$ year & $35-55$ year & $\geq 56$ year \\
\hline Male & $3-5$ & 5 & $5-13$ & $8-22$ & $10-25$ & $22-25$ \\
\hline Female & $8-12$ & $8-12$ & $12-22$ & $20-35$ & $25-38$ \\
\hline
\end{tabular}

Source: Data based on american collage of sport medicine 2014, ACSM's guidelines for exercise terting and prescripe, $8^{\text {th }}$ ed (philadelphia: Lea \& Febiger) dalam bukunya (James R. Marrow, Mood, Disch, \& Kang, 2016) yang berjudul Measurement and Evaluation in Humen Performance

Fitness is orginated from the word fit, and fit means health. According to Giriwijoyo \& Sidik (2013), "Other terms related to fitness are: 1) Freshness, 2) Capability, and 3) Alacrity. Fitness is a combination of sports and activities conducted at a sports center or at home. In other words, "Sports are activities that involve physical abilities, physical fitness or physical skills that usually, but not always, involve competition between two or more people (Lori A. Smolin, 2010). Hence, it can be concluded that physical fitness is human body's ability to function effectively when doing activities, and still has sufficient energy to handle or deal with any emergencies that may occur" (Shearer et al., 2020).

Before increasing the physical fitness, it is necessary to know the type of the exercise, since the better the exercise, the higher the physical fitness. According to Widiastuti (2015) "physical fitness relates to physical health, such as: (a) cardiorespiratory, (b) muscular strength, (c) muscular endurance, (d) flexibility, and (e) body composition. Hence, it can be concluded that the process of increasing physical exercise will improve athletes' physical fitness.

According to Giriwijoyo \& Sidik (2013:316), exercise is a conscious effort conducted continuously and systematically in order to improve the functional abilities of the body, based on the demands of the task / the performance, such as physical abilities and technical abilities. Meanwhile, according to Indonesian Professional Sports Development and Supervision Agency (2007) "Exercise is a systematic and progressive activity conducted for a long period of time based on someone's capability level, in order to establish physiological and psychological functions which are suitable with sports activities." Meanwhile, according to Bompa \& Haff (2009), "Exercise is an athlete's process in preparing his performance. The aim of the exercise is to improve athletes' capability for achieving optimal athletic work." Then, according to Tangkudung (2018), "The goal can be achieved by implementing an appropriate exercise, based on the principles of exercise". The exercise program is arranged based on athletes' conditions, while their success depends on their own quality and ability.

Based on previous explanations, physical fitness is the body's ability to function effectively when doing activities, and still has sufficient energy to handle or deal with any emergencies that may occur. Meanwhile, exercise is a systematic and planned way to improve physiological, psychological, and movement skills, in order to achieve the best performance. Thus, the exercise should be suitable with its principles.

According to Bompa \& Haff (2009), "the principles of exercise are: multilateral development rather than specialization, individualization, exercise model development, increased load, and a series of exercise loadings." Someone can be able to create exercise programs if he is able to measure them. Exercise programs can help to ensure and achieve the goals. According to Stone (2013: 29), "The principle of FlTT are: $F=$ frequency, $\mathrm{I}=$ Intensity, $\mathrm{T}=$ Time, and $\mathrm{T}$ : Type of exercise". In addition, warming up and cooling down stages in the exercise are also important, based on the initial level of physical fitness and the goals. " Then "can exercise burn fat?" The answer is "Yes". In fact, exercise is 
the only activity that burns fat significantly rather than other rough works such as farmers, porters, or pedicab rickshaws. If you want to burn more fat, you need more efforts in aerobic exercise. Meanwhile, when you want to tighten your body, the focus is exercise load (Pahaidon L. Toruan, 2015). A person's physical fitness can be checked by doing aerobic exercise, such as measuring the performance of the heart and lungs, by using Harvard Step Test. The assessment categories in Harvard Step Test are as follows:

Table 2. Assesment Categories $(\mathrm{N}=14)$

\begin{tabular}{cc}
\hline Norm Values & Notes \\
\hline$>90$ & Excellent \\
$80-89$ & Good \\
$65-79$ & Average \\
$55-64$ & Below Average \\
$<55$ & Poor \\
\hline
\end{tabular}

Source: Https://www.volimaniak.com/

2016 /02/tatacara-melakukan-pengujian-harvard-step-test.html

\section{Research Method}

The researcher implemented causal studies and path analysis. Causal studies aim to determine whether the independent variable or dependent variable affected the outcome In causal studies, the cause is considered as the independent variable, while the effect is the dependent variable.

Meanwhile, the variables in the path analysis consist of exogenous (cause) and endogenous (result) variables. This is based on the study of the problems the objectives of this study.

This research was conducted in National Sports Committee of Indonesia, specifically in Karawang Regency, and selected the athletes as the respondents. Fourteen (14) respondents were selected by purposive sampling, while the criteria were athletes who have invested more than 2 years in training and have excess weight. Data were collected by using Harvard step test in order to measure the physical fitness, and Bioelectrical Impedance Analysis (BIA) data in order to measure the body fat.

\section{Results of the Study}

1. In body fat variable, the results are: the mean $=50.00$; standard deviation $=9.92 ;$ variance $=98.3077$; median $=47.5$; and mode $=39$. The classification of body fat data are as follows:

Table 3. Frequency Distribution Table of The Athletes’ Body Fat N=14

\begin{tabular}{|c|c|c|c|c|c|c|}
\hline \multirow{2}{*}{ No } & \multirow{2}{*}{$\begin{array}{c}\text { Interval } \\
\text { Class }\end{array}$} & \multicolumn{2}{|c|}{ Limits } & \multicolumn{3}{c|}{ Frequency } \\
\cline { 3 - 7 } & Below & Above & Absolute & Relative & Communicative \\
\hline 1 & $39-45$ & 38,5 & 45,5 & 5 & $35,71 \%$ & $35,71 \%$ \\
\hline 2 & $46-52$ & 45,5 & 52,5 & 3 & $21,43 \%$ & $57,14 \%$ \\
\hline 3 & $53-59$ & 52,5 & 59,5 & 4 & $28,57 \%$ & $85,71 \%$ \\
\hline 4 & $60-66$ & 59,5 & 66,5 & 1 & $7,14 \%$ & $92,86 \%$ \\
\hline 5 & $67-73$ & 66,5 & 73,5 & 1 & $7,14 \%$ & $100 \%$ \\
\hline
\end{tabular}


Based on table 3, the histogram is made based on two axes, such as making vertical axis as the absolute frequency axis, and horizontal axis as the body fat score axis. In this case, on the horizontal axis, the limits of the interval class are showed, ranging from 38.5 to 73.5 . These scores are obtained by subtracting ` 0.5 from the smallest data, and adding 0.5 for each class boundary at the highest limit. The histogram is as follow:

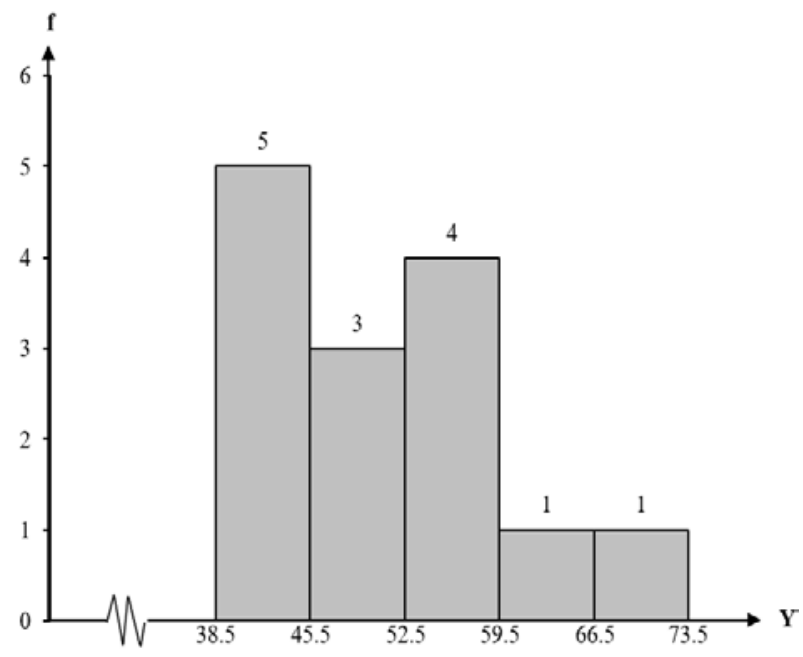

Figure 1. The Histogram of Body Fat Data

2. In physical fitness variable, the results are: the mean $=87.43$; standard deviation $=23,128$; variance of 534.5714; median $=89.0$; and mode $=92$. The classification of physical fitness data are as follows:

Table 4. Frequency Distribution Table of the Athletes’ Physical Fitness $(\mathrm{N}=14)$

\begin{tabular}{|c|c|c|c|c|c|c|}
\hline \multirow{2}{*}{ No } & \multirow{2}{*}{$\begin{array}{c}\text { Interval } \\
\text { Class }\end{array}$} & \multicolumn{2}{|c|}{ Limits } & \multicolumn{3}{c|}{ Frequency } \\
\cline { 3 - 7 } & Below & Above & Absolute & Relative & Communicative \\
\hline 1 & $48-61$ & 47,5 & 61,5 & 2 & $14,29 \%$ & $14,29 \%$ \\
\hline 2 & $62-75$ & 61,5 & 75,5 & 2 & $14,29 \%$ & $25,87 \%$ \\
\hline 3 & $76-89$ & 75,5 & 89,5 & 3 & $21,43 \%$ & $50,00 \%$ \\
\hline 4 & $90-103$ & 89,5 & 103,5 & 2 & $14,29 \%$ & $64,29 \%$ \\
\hline 5 & $104-117$ & 103,5 & 117,5 & 5 & $35,71 \%$ & $100 \%$ \\
\hline \multicolumn{7}{|c|}{$14 \%$} \\
\hline
\end{tabular}

Based on table 4, the histogram is made based on two axes, such as vertical axis as the absolute frequency axis, and the horizontal axis as the fitness score axis. In this case, on the horizontal axis, limits of the interval class ranging from 47.5 to 117.5. These scores are obtained by subtracting 0.5 from the smallest data and adding 0.5 for each class boundary at the highest limit. The histogram is as follow:

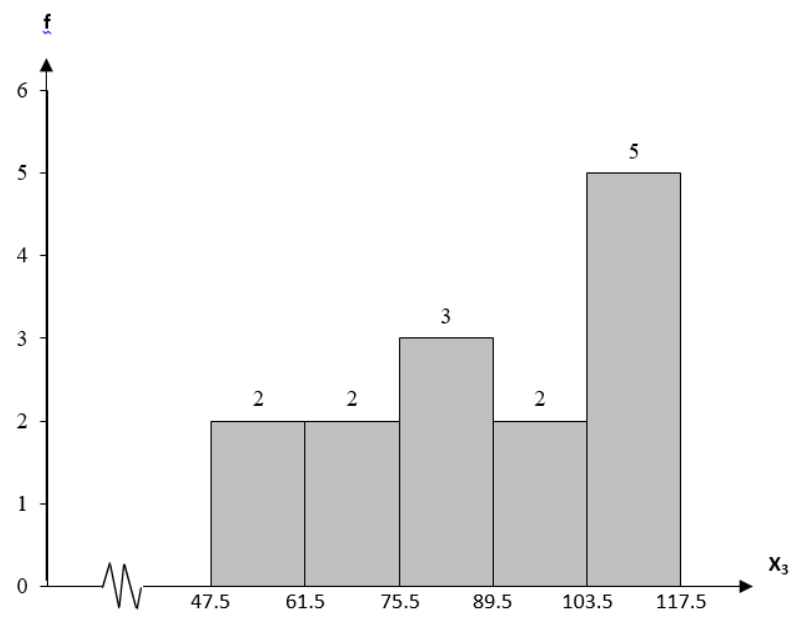

Figure 2. The Histogram of Physical Fitness Data 
From the data of regression equation model between body fat and physical fitness, it is found that the constant $\mathrm{a}=$ 76.344 and the regression coefficient $b=-0.301$. Thus, the relationship of the simple regression equation model is $\hat{Y}=$ $76.344-0.301 X 3$. Before the regression equation model is analyzed and used in drawing conclusions, the significance and linearity of the regression equation were tested.

Table 5. The test of Significance and Linearity ANAVA, $\hat{Y}=75,03-0,35 X 3(N=14)$

\begin{tabular}{|c|c|c|c|c|c|}
\hline Sources of Variance & $\mathrm{dk}$ & $\mathrm{JK}$ & RJK & Fcount & Ftable \\
\hline Total & 14 & 36278 & & & \\
\hline Coefficient (a) & 1 & 35000,00 & & & \\
\hline Regression (b/a) & 1 & 630,96 & 630,96 & $11,702 * *$ & 4,75 \\
\hline Residue & 12 & 647,04 & 53,92 & & \\
\hline RJKTC & 10 & 478,04 & 47,80 & $0,566 \mathrm{~ns}$ & 19,40 \\
\hline Error & 2 & 169,00 & 84,50 & & \\
\hline
\end{tabular}

Regression equation $\hat{\mathrm{Y}}=76.344-0.301 \mathrm{X} 3$, for the significance test: $\mathrm{F}_{\text {count }}=11.702$ is greater than $\mathrm{F}_{\text {table }}(0.05$; $1: 14)=4.75$ at $\alpha=0.05$. Since $F_{\text {count }}>F_{\text {table, }}$, the regression equation is considered as significant. For the linearity test, $\mathrm{F}_{\text {count }}=0.566$ is smaller than $\mathrm{F}_{\text {table }}(0.05 ; 10: 2)=19.40$ at $\alpha$ $=0.05$. Since $\mathrm{F}_{\text {count }}<\mathrm{F}_{\text {table, }}$, then distribution of point estimation which forms a linear line is acceptable.

Based on the results, in order to answer the hypothesis about the effect of physical fitness to the body fat, the hypothesis tested are:

$$
\begin{aligned}
& \mathrm{H}_{0}: \beta_{\mathrm{y} 1}>0 \\
& \mathrm{H}_{1}: \beta_{\mathrm{y} 1}<0
\end{aligned}
$$

Then, the path coefficient value of the exercise to body fat is -0.212 , while the $t_{\text {count }}$ is -2.468 . In other words, the value of $t_{\text {count }}$ is smaller than the value of $t_{\text {table, }}$ while $d k=9$, $\alpha(0.05)=-2.26$, and the probability value of Sig. $(0.036)<$ significant level (0.05). Hence, $\mathrm{H}_{0}$ is rejected and $\mathrm{H}_{1}$ is accepted, or there is a significant and direct negative effect of exercise variables on body fat variables.

\section{Discussion}

The results of hypothesis revealed that physical fitness has a direct negative effect on body fat. Based on the result, it can be concluded that the increase of physical fitness will result a decrease in body fat, proved by the statistical data. The results of this study are in line with other previous statements, such as many athletes can reduce their body fat through physical exercise in order to improve their physical fitness, but some of the exercise programs do not always run smoothly. Phaidon L. Toruan (2015:14) states that "not all people practice sports in extreme ways, for example in doing aerobic, they can do the exercise twice a day, for six days in a week; or they can run for hours everyday. However, the body fat is not reduced if the person consumes more unhealthy food. Then, athletes who have excess weight also have difficulties in losing weight. A significant difference in the $\mathrm{VO} 2$ max of males and females after the multistage jumping rope training program is revealed [13]. According to the previous research conducted by Shinta Paramita (2012:9), even when a group of obese people have completed 12 weeks of Cardio exercises and monitored by the coach, it will not be effective when they do not change their eating patterns. In other words, they will not experience significant weight loss. " Combination of aerobic exercise and weight training can reduce participants' body weight, body fat and waist circumference, both in the normal diet and low-calorie diet groups [15].

Another fact stated by (Kerri Winter Stone, 2013:25) is that "Body composition is the total fat and muscle mass in the body, and also called as the percentage of total body mass, for example the percentage of body fat. An athlete is considered "thin", if the athlete generally has a lot of muscles or less fat. Someone who has high percentage of body fat relatively has lower amount of muscles. The first example, is that the person can have a higher risk for chronic diseases related to body fat, such as heart disease, stroke, diabetes, hypertension, and cancer. The second example is that the person has a high risk for any diseases related to lack of muscle mass, such as poor physical function, unhealthy bones, or a high risk of falling". Then, according to Papadopoulou (2010), athletes with higher levels of body fat can have more difficulties, since it can be found in vitamins A, B1, B12, folic acid, and minerals P and $\mathrm{Mn}$, while $\mathrm{p}<0.05$, compared to other athletes.

In addition, according to Lanham-New et al., (2016:379), there are several conditions that increase the athlete's body fat beyond the ideal or healthy limit. A common example is that when the athletes come back after getting injured, their body fat can be increased significantly than their body weight." Meanwhile, according to Balaban \& Bobick (2014:118), the muscles can turn into body fat if someone stops exercising. The muscles begin to shrink and the body fat begins to expand. However, when the muscles turn into fat, the number of muscle cells are not changed. "

Generally, exercise is a systematic and progressive activity conducted for a long period of time, based on 
someone's capability level, such as physiological and psychological functions that are suitable with sports activities. The higher the exercise level, the better the performance achieved. In addition, exercise is useful in burning body fat.

Another finding revealed by Shigeo Haruyama (2015:159), when someone has sufficient amount of muscles, $60 \%$ of the fat will be burned. Meanwhile, if a person has lower amount of muscles, only $30 \%$ of the calories are burned, and the rest (30\%) will be stored as body fat.

The main issue discussed currently is how to burn calories with speed, power and muscle building approaches, since people consume the food based on its taste, not its composition. Then, several fitness centers are provided in order to increase atlethes' or other societies' strength, muscles, and agilities.

\section{Limitations of the Study}

This study only explains the effect of physical fitness on body fat in National Sports Committee of Indonesia in Karawang regency, while it can be better for conducting further researches with a wider number of samples. In addition, in this study, the data obtained only through Harvard step test, by using a stopwatch and a metronome to measure athletes' physical fitness and obtain Bioelectrical impedance analysis (BIA) data, and select the respondents based on the requirements (2 variables).

In addition, the distribution of research instrument was only conducted once, based on valid and reliable statistical calculations, and there might be any weakness in the instrument.

The limitations of this study will provide opportunities for other researchers who are interested conduct further research related to body fat.

\section{Conclusion and Suggestion}

\subsection{Conclusion}

Based on the results, it can be concluded that physical fitness significantly has a direct negative effect on the body fat, or in other words, even when the athlete's physical fitness is better, it does not guarantee his body fat is also good.

\subsection{Suggestions}

a) Based on the result of this study, it can be identified that physical fitness significantly has a direct negative effect on the body fat. Hence, the athletes should arrange their eating pattern, in order to prevent other negative impacts. b) In order to reduce body fat, other researchers, trainers, doctors, and coaches can examine physical fitness from other aspects, such as stress, overload, and other motivations related to weight or body fat loss.

\section{Acknowledgement}

My achievements are the anwers of the prayers from all of you. Thank you for all wishes and prayers given to me.

\section{REFERENCES}

[1] Susan A. Lanham-New, I. A. Macdonald., And H. M. Roche, METABOLISME ZAT GIZI, 2nd Ed. Jakarta: Buku Kedokteran EGC, 2016.

[2] Syakhustiani, Jurnal Olahraga Pendidikan, 1st Ed., Vol. 1. Jakarta: ASISTEN DEPUTI OLAHRAGA PENDIDIKAN DEPUTI BIDANG PEMBUDAYAAN OLAHRAGA KEMENTERIAN PEMUDA DAN OLAHRAGA REPUBLIK INDONESIA, 2014.

[3] B. J. Sharkey, Physiology Of Fitness, Vol. 91. United States Of America: Library Of Congress Cataloging, 2012.

[4] S. Giriwijoyo And D. Z. Sidik, Fisiologi Olahraga, 2nd Ed. Bandung: PT. Remaja Rosdakarya, 2013.

[5] M. . B. G. Lori A. Smolin, Nutrition For Sports And Excercise. 2010.

[6] J. Shearer, L. Agius, N. Burke, M. B. B. C. H. Bao, R. Rahardja, And S. W. Young, "BMI Is A Better Predictor Of Periprosthetic Joint Infection Risk Than Local Measures Of Adipose Tissue Following TKA,” J. Arthroplasty, 2020, Doi: 10.1016/J.Arth.2020.01.048

[7] Widiastuti, Tes Dan Pengukuran Olahraga, 1st Ed. Jakarta: PT. Raja Grafindo Persada, 2015.

[8] T. O. Bompa And G. G. Haff, Periodization: Theory And Methodology Of Training, 5th Ed. United States Of America: Human Kinetics, 2009.

[9] J. Tangkudung, SPORT PSYCHOMETRICS : Dasar-Dasar Dan Instrumen Psikometri Olahraga, 1st Ed., No. October. Depok: PT. Raja Grafindo Persada, 2018.

[10] K. W. Stone, Program Olahraga: Osteoporisis. Panduan Untuk Tulang Yang Lebih Kuat Dan Sehat. Yogyakarta: PT. Citra Aji Parama, 2013.

[11] Pahaidon L. Toruan, The New Fat-Loss Not Weight-Loss: Gemuk Tapi Ramping, 1st Ed. Jakarta Selatan: Trans Media Pustaka, 2015.

[12] Phaidon L. Toruan, The New Fat-Loss Not Weight-Loss: Gemuk Tapi Ramping, 1st Ed. Jakarta: Trans Media Pustaka, 2015.

[13] H. C. Dimarucot And G. P. Soriano, "Effectiveness Of The Multistage Jumping Rope Program In Enhancing The Physical Fitness Levels Among University Students,” Vol. 8, No. 5, Pp. 235-239, 2020, Doi: 10.13189/saj.2020.080511. 
[14] Shinta Paramita, Sehat Dan Bugar Dengan Terapi Jus Buah \& Sayur. Jakarta: Lintas Media, 2012.

[15] Padli, Y. Kiram, S. Syahara, And H. S. Lesmana, “Combined Effects Of Weight Training And Aerobic Exercise Accompanied By Normal And Low-Calorie Diets On Fat Percentage Of Young Women,” Int. J. Hum. Mov. Sport. Sci., Vol. 8, No. 5, Pp. 283-291, 2020, Doi: 10.13189/saj.2020.080517.

[16]K. Winter-Stone, Program Olahraga: Osteoporosis. Panduan Untuk Tulang Yang Lebih Kuat Dan Sehat. Yogyakarta: PT. Citra Aji Parama, 2013.

[17] S. K. Papadopoulou And S. D. Papadopoulou, "Nutritional
Status Of Top Team-Sport Athletes According To Body Fat," Nutr. Food Sci., Vol. 40, No. 1, Pp. 64-73, 2010, Doi: 10.1108/00346651011015935.

[18] N. E. Balaban And J. E. Bobick, Seri Ilmu Pengetahuan Anatomi Dan Fisiologi, 1st Ed. Jakarta Barat: PT. Indeks, 2014.

[19] Shigeo Haruyama, The Miracle Of Endorphin, Cetakan 1. Bandung: Qanita, 2015.

[20] J. James R. Marrow, D. P. Mood, J. G. Disch, And M. Kang, Measurement And Evaluation In Humen Performance, 5th Ed., Vol. 11, No. 3. America: United State Of America, 2016. 